\title{
PPE pollution in the terrestrial and aquatic environment of the Chittagong city area associated with the COVID-19 pandemic and concomitant health implications
}

\author{
Md. Jainal Abedin ${ }^{1} \cdot$ Mayeen Uddin Khandaker ${ }^{2}$ (I) $\cdot$ Md. Ripaj Uddin ${ }^{3} \cdot$ Md. Rezaul Karim ${ }^{4}$. \\ M. Shahab Uddin Ahamad ${ }^{5} \cdot$ Md. Ariful Islam ${ }^{4}$ - Abu Mohammad Arif ${ }^{6}$. Abdelmoneim Sulieman ${ }^{7}$. \\ Abubakr M. Idris ${ }^{8,9}$
}

Received: 7 October 2021 / Accepted: 26 November 2021 / Published online: 4 January 2022

๑) The Author(s), under exclusive licence to Springer-Verlag GmbH Germany, part of Springer Nature 2021

\begin{abstract}
The present study focuses on the indiscriminate disposal of personal protective equipment (PPEs) and resulting environmental contamination during the 3rd wave of COVID-19-driven global pandemic in the Chittagong metropolitan area, Bangladesh. Because of the very high rate of infection by the delta variant of this virus, the use of PPEs by the public is increased significantly to protect the ingestion/inhalation of respiratory droplets in the air. However, it is a matter of solicitude that general people throw away the PPEs to the dwelling environment unconsciously. With the increase of inappropriate disposal of PPEs (i.e., mostly the disposable face masks made from plastic microfibers), the possibility of transmission of the virus to the general public cannot be neglected completely. This is because this virus can survive for several days on the inanimate matter like plastics and fibers. At the same time, the result of environmental contamination by microplastic/microfiber has been widespread which eventually creates the worst impact on ecosystems and organisms. The present results may help to increase public perception of the use and subsequent disposal of PPEs, especially the face masks.
\end{abstract}

Keywords PPEs $\cdot$ Pandemic $\cdot$ COVID-19 $\cdot$ Disposal $\cdot$ Environmental contamination

\section{Introduction}

Chittagong is the commercial capital city of Bangladesh. The current population of the Chittagong metropolitan area (CMA) is about 5,133,000 (CMA population 2021). It is now one of the densely populated cities in Bangladesh.

Responsible Editor: Lotfi Aleya

Mayeen Uddin Khandaker

mu_khandaker@yahoo.com; mayeenk@sunway.edu.my

1 Faculty of Public Health, Thammasat University, Bangkok 10200, Thailand

2 Centre for Applied Physics and Radiation Technologies, School of Engineering and Technology, Sunway University, 47500 Bandar Sunway, Selangor, Malaysia

3 Institute of National Analytical Research and Service (INARS), BCSIR, Dhanmondi, Dhaka 1205, Bangladesh

4 Department of Chemistry, Chittagong University of Engineering and Technology, Chattogram 4349, Bangladesh
The pollution of the dwelling environment is increasing cumulatively following the population growth as well as from the operation of production and extractive industries within the city area. In addition, the COVID-19 pandemic is adding extra pollution to the dwelling and aquatic environment. The world health organization (WHO) states that COVID-19 is highly contagious and shows transmission via human contact including from asymptomatic individuals and

5 Department of Pathology, Chittagong Medical College, Chattogram 4302, Bangladesh

6 One Health Institute, Chattogram Veterinary and Animal Sciences University, Chattogram 4225, Bangladesh

7 Department of Radiology and Medical Imaging, College of Applied Medical Sciences, Prince Sattam Bin Abdulaziz University, P.O. Box 422, Alkharj 11942, Saudi Arabia

8 Department of Chemistry, College of Science, King Khalid University, Abha, Saudi Arabia

9 Research Center for Advanced Materials Science (RCAMS), King Khalid University, Abha, Saudi Arabia 
through aerosols and airborne droplets (Prather et al. 2020). Therefore, WHO suggested using face masks as the primary media as personal protective equipment (PPE). The use of face masks may work in both ways, reducing the release and ingestion/inhalation of particles, hence protecting the wearer (Prather et al. 2020). The first COVID-19 case was identified in CMA after the testing of 55 samples at the Tropical and Infectious Disease Institute in Bangladesh on 3rd April 2020. The present COVID-19 cases in CMA are 67,894 (from 4th April to 31st July 2021), and the death rate is significantly increased in the $3 \mathrm{rd}$ wave. As a result, the demand and use of PPEs undoubtedly increased throughout the city area. PPEs are classified as face masks, gloves, hand sanitizer, and other important safety equipment which is used to protect the transmission of the SARS-CoV-2 virus. Among the PPEs, especially face masks are usually made by one-time-use plastics (Patel et al. 2017) such as high-density polyethylene (HDPE), polypropylene (PP), polystyrene, polycarbonate, and polynitrile (Chua et al. 2020; Fadare and Okoffo 2020). The three-layered face mask was designed and constructed as follows: inner layer works as absorbent made by cotton, the middle layer is a non-woven and nonabsorbent material such as polypropylene, and another layer is of non-absorbent material such as polyester blend or polyester. The PPEs are non-degradable and remain a long time in the environment. Moreover, these PPEs are moved from one place to other via streams, wind, rivers, and waters, and under various environmental conditions; these break down into microplastic/microfiber and contaminate the dwelling environment (Liubartseva et al. 2016; Andrady 2017). The extensive uses of PPEs are generating tones of microplastic/ microfiber wastes in the environment. As a result, pollution of the terrestrial and aquatic environment is increasing significantly day by day. Due to the non-biodegradability of plastic, the PPE residues will likely remain as common debris in the terrestrial and aquatic environment for decades, which potentially affects the biota and biological systems (Fig. 1). Consequently, it poses a threat to aquatic lives, which is a major constituent of the food web and, hence, poses a non-negligible concern on food safety worldwide (Fadare et al. 2020).

The PPE's debris can easily adsorb organic and inorganic nutrients from the environment, which then provide a suitable habitat for pathogenic bacteria and viruses, hence enhancing their diffusivity (Frère et al. 2018). A preliminary study on everyday surfaces in households or hospital settings shows that the SARS-CoV-2 virus in plastic items or surfaces can be survived for several hours after direct contamination (Doremalen et al. 2020). As a result, the idea of using single-use plastics to reduce SARS-CoV-2 transmission may pose an extra threat to public health, following the indiscriminate disposal of PPE. Although the primary route of SARS-CoV-2 transmission occurs via human contact or respiratory droplets, nevertheless, the contact with surfaces (fomites) can be a secondary or extra route of exposure to the virus (Perlman 2020; Zeri and Naroo 2020). In this way, it has become an occupational risk for operators involved in waste management and garbage collectors as well. Although there is no relevant proper evidence for SARS-CoV-2 (WHO, 2020), there has been a report on the risk factor due to the handling of contaminated waste from MERS-CoV patients (Arwady et al. 2016). SARS-CoV-2 can survive on objects for a long time, potentially remaining infectious through numerous surfaces, including trash cans
Fig. 1 Impact of microplastic pollution on aquatic lives, environmental degradation, and health disorder

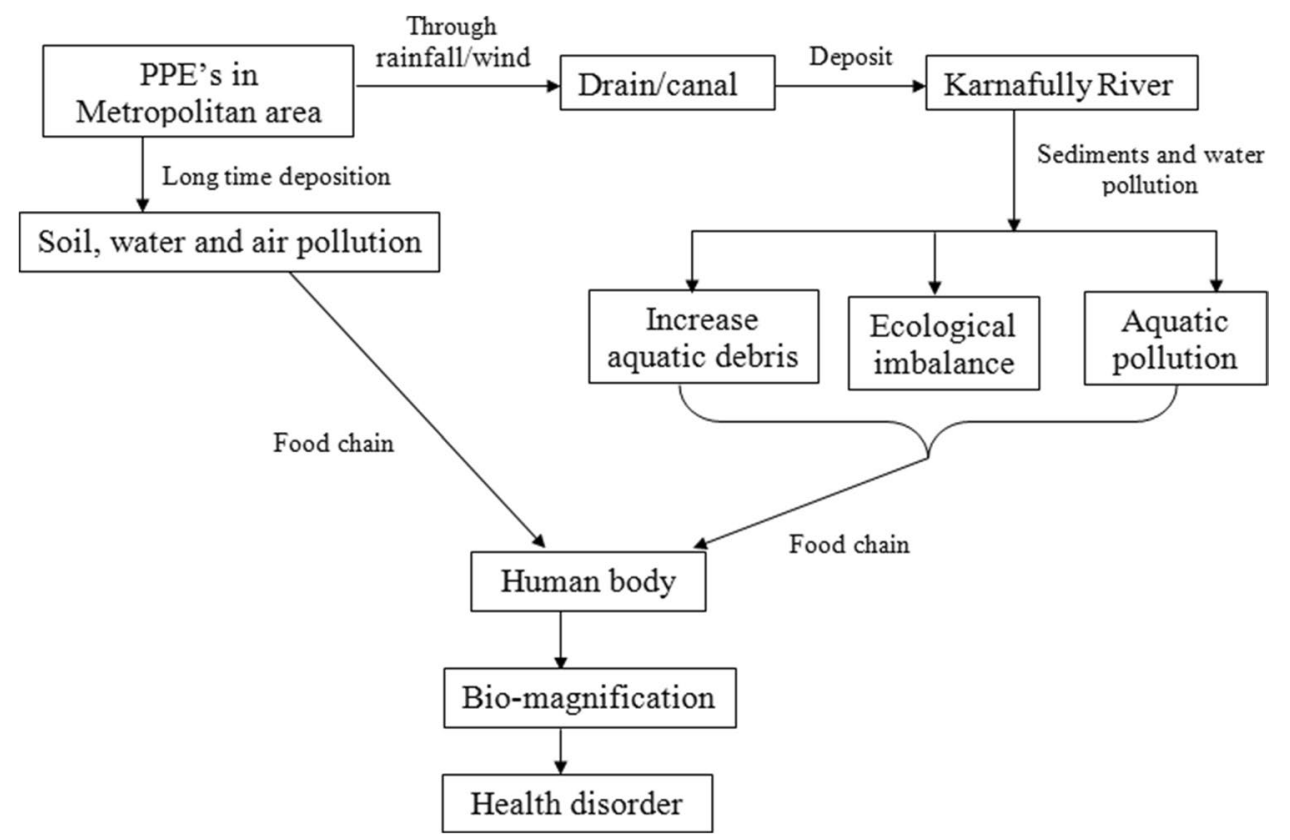


and face masks even after disposal for up to 7 to 30 days (Young 2020). Contamination could result from the contact of soiled hands or the spread of aerosol particles (Dietz et al., 2020; Nghiem et al. 2020). Therefore, proper strategies on the handling and disposal of PPEs waste should be taken into account to avoid the extra route of transmission of the SARS-CoV-2 (WHO 2020). It has been observed that necessary financial support for proper protective strategies (e.g., viable PPE waste management practices and procedures) during the COVID-19 pandemic is absent in many low- and middle-income countries. Considering the potential infectious threat from PPE residues, some countries have already provided recommendations for regulating national waste management. In developed countries, the primary method of the disposal of infectious medical waste is incineration under high temperatures, followed by landfilling residual ash (Windfeld and Brooks 2015). For example, the Portuguese Environmental Agency (2020) also recommends a similar procedure, i.e., to dispose of all potentially contaminated domestic residues including PPEs as mixed wastes in sealed and leak-proof garbage bags, and then treated by incineration, or by daily landfilling. This disposal method may act as a viable technique to avoid the public health risk from infectious wastes despite the drawbacks of incineration which requires strict protocol about gas emissions (Prata et al. 2019). Despite the COVID-19 pandemic, most of the developing countries including the Philippines, Cambodia, India, Thailand, Vietnam, Indonesia, and Bangladesh are still engaged in the traditional system of solid waste management, i.e., dumping the solid waste as open landfills without any pre-treatment through the treatment plant (World Bank 2019; Ferronato and Torretta 2019). Since the mismanaged PPEs can act as a potential vector to enhance the global plastic contamination and transmission of SARS-CoV-2, therefore, it is important to reinforce proper disposal of used PPE in sealed garbage bags followed by incineration under high temperatures. The emergence of face masks has evidenced that the COVID-19 pandemic increased the challenge of plastic pollution in the terrestrial and aquatic environment (Reid et al. 2019; Shen et al. 2019).

Bangladesh's government has made mandatory the use of face masks in public places and initiated "no mask, no service" (The Prothom Alo, 2nd November 2020). Following the government declaration, wearing face masks has become a widespread practice in Bangladesh to abate COVID-19 transmission. However, a significant amount of PPEs, especially contaminated face masks, are in the process of becoming infectious waste. Following the improper handling or unsafe disposal of the healthcare waste owing to the COVID-19 pandemic, both the human health and dwelling environment are experiencing an immediate and significant threat (Singh et al. 2020; Nzediegwu and Chang 2020). This has been revealed by a few recent studies. As an example,
Kampf et al. (2020) reported that SARS-CoV-2 can remain active on inanimate hard surfaces for up to 9 days. Fahmida et al. (2021) detected microplastics (MPs) composed of EVA, HDPE, PE, and PP polymers in the gastrointestinal tract of different freshwater fish species in Bangladesh (Jagrata Juba Shangha 2021). Hossain et al. (2019) detected the MPs in the intestines of marine fishes from the Northern Bay of Bengal (Fahmida et al. 2021). The studied fish species are commonly found in the local market in Bangladesh, and people consume them as their daily diet to meet the protein demand. These studies indicate that microplastic pollution to the terrestrial and aquatic environment has increased rapidly in recent times. This also indicates that the mismanaged PPEs and solid wastes may become the root cause of severe diseases and environmental problems (Nzediegwu and Chang 2020). In these circumstances, the present study has been carried out to (i) identify PPE debris abundance and densities in different contexts in the Chittagong metropolitan area, (ii) quantify the PPE debris and types in the study area, (iii) calculate the COVID-19-driven medical waste generation in CMA, and (iv) assessing the concomitant health risk and environmental pollution in the study area. As far as our concern, this study forms the first comprehensive efforts for the aforementioned activities in the Chittagong metropolis. This research may help the respective authority for the proper management of PPE waste during this pandemic.

\section{Materials and methods}

\section{Study area and PPE monitoring}

By considering a range of human activity, the monitoring was conducted on four consecutive weeks in July 2021 at twenty-one (21) locations such as residential areas, commercial areas, bus stations, marine bay area, city junction/ crowded area, port area, and hospital areas in CMA (Fig. 2). Locations were selected with particular reason to observe the actual variation of PPE's waste distribution. The survey took place during the 3rd wave of COVID-19 (1st July to 31st July 2021) when the rate of infection was gradually increased to a peak point. The sampling campaign was performed by walking along streets/convenient pathways/busy areas in CMA, visual observation of the surroundings, and identification of the PPE items followed by photographed and recorded (Fig. 3). Dumpsites in the metropolitan area were also surveyed. The same sampling point was surveyed several times every after 4 days to avoid sampling bias. A self-designed stick (metal) equipped with a hand-held claw was used to collect the PPE debris to prevent exposure from direct contact. Following the easy visibility, various types of debris from drains, canal sides, Karnafully river sites, etc. were collected/recorded. A spray-type hand sanitizer 

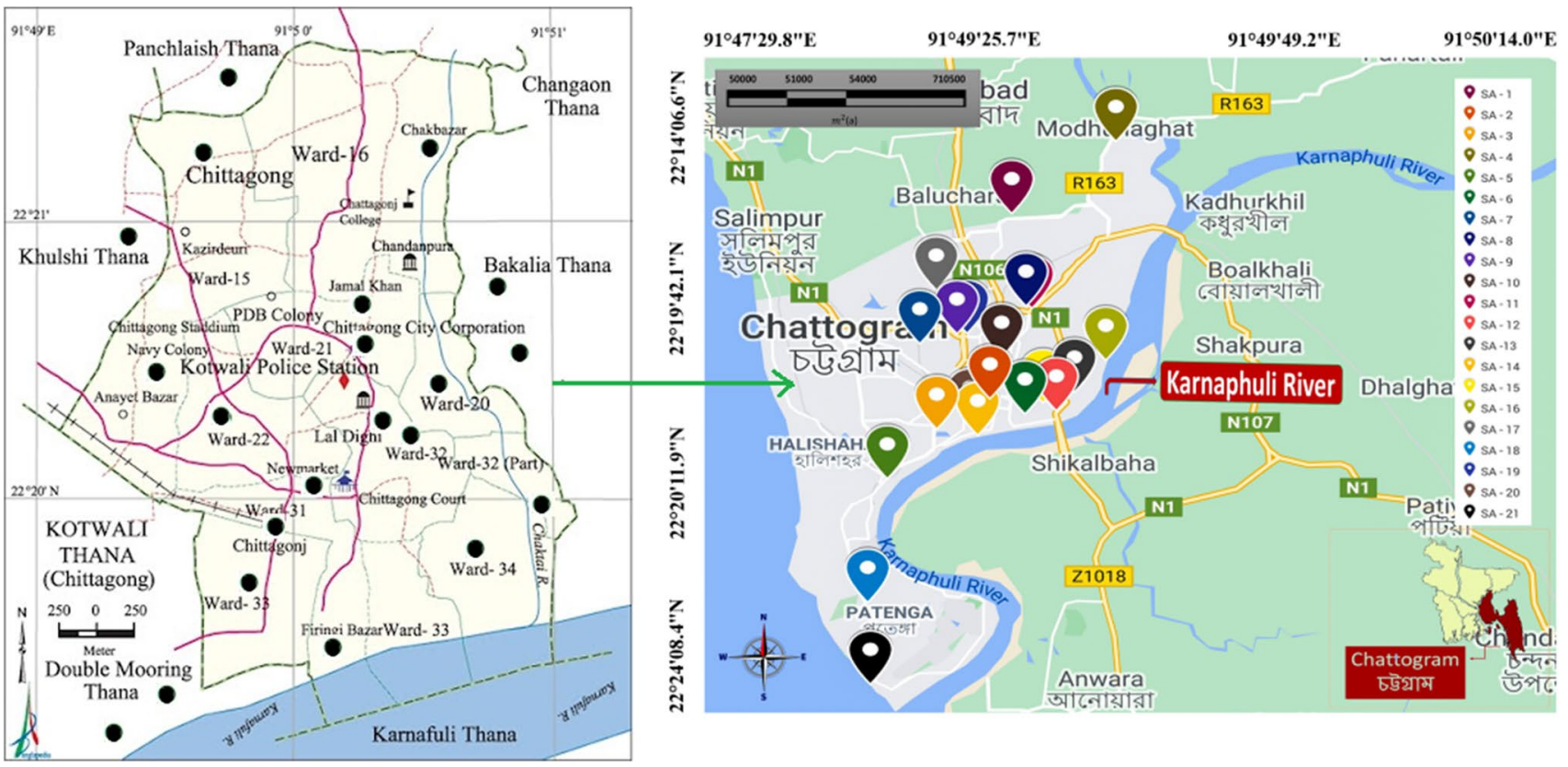

Fig. 2 Sampling area

was frequently used throughout the sample collection campaign. A mobile application was used to document the identified PPE debris from various environments and locations. It also records the GPS coordinates and collection dates, debris items, and types (i.e., face masks, gloves, etc.). Google Earth Pro was used to measure the distances among the surveyed places. The non-PPE debris was skipped from this study. The recorded face masks were categorized into various types: dust masks, surgical masks, reusable masks, and medical masks (i.e., KN95 and N95). The collected disposable gloves were classified based on their material types, color, and texture: vinyl (translucent), nitrile (black or blue), polyethylene, and latex (white). No information could be obtained about what types of disinfectant wipes were initially used before becoming debris. The color of face masks in the Chaktaikhal changed due to the tidal and wastewater color. On the other hand, for the estimation of face masks and medical wastes, necessary data were collected from the Civil Surgeon Office of Chittagong (https://www.facebook. com/pages/Civil-Surgeon-Office-Chittagong/1752488248 331436).

\section{Data analysis and visualization}

The collected data were arranged systematically. Table 1 shows the sampling area of each site and the corresponding GPS coordinates. To obtain the information on PPE waste abundance, all sampling sites were randomly monitored (Fig. 2) for four consecutive weeks. The abundance was calculated by using the recorded data on every survey day at each location and then determined the total amount of PPE debris. The collected PPE items or debris density was calculated using Eq. (1) (Okuku et al. 2020; Mol and Caldas 2020):

$C=n / a$

where $C$ represents the PPE density in the unit of (item/ $\left.\mathrm{m}^{2}\right), n$ is the number of recorded or counted PPE, and $a$ is the area where PPE items were detected.

\section{Quantification of facemask wastes generated in CMA in July 2021}

\section{Estimation of disposable facemask waste by the general population in CMA}

The estimation of daily facemask disposal depends on several factors: the total population in a certain area, the percentage of the urban population residing in that area, facemask acceptance rate, and mean daily disposal of face mask per capita. The total amount of facemask wastes generated during the 3rd wave of COVID-19 pandemic in July 2021 was determined using Eq. (2) (Boroujeni et al. 2021; Mol and Caldas 2020; Haque et al. 2020):

$T W_{F}=F M_{D} \times W_{F}$ 

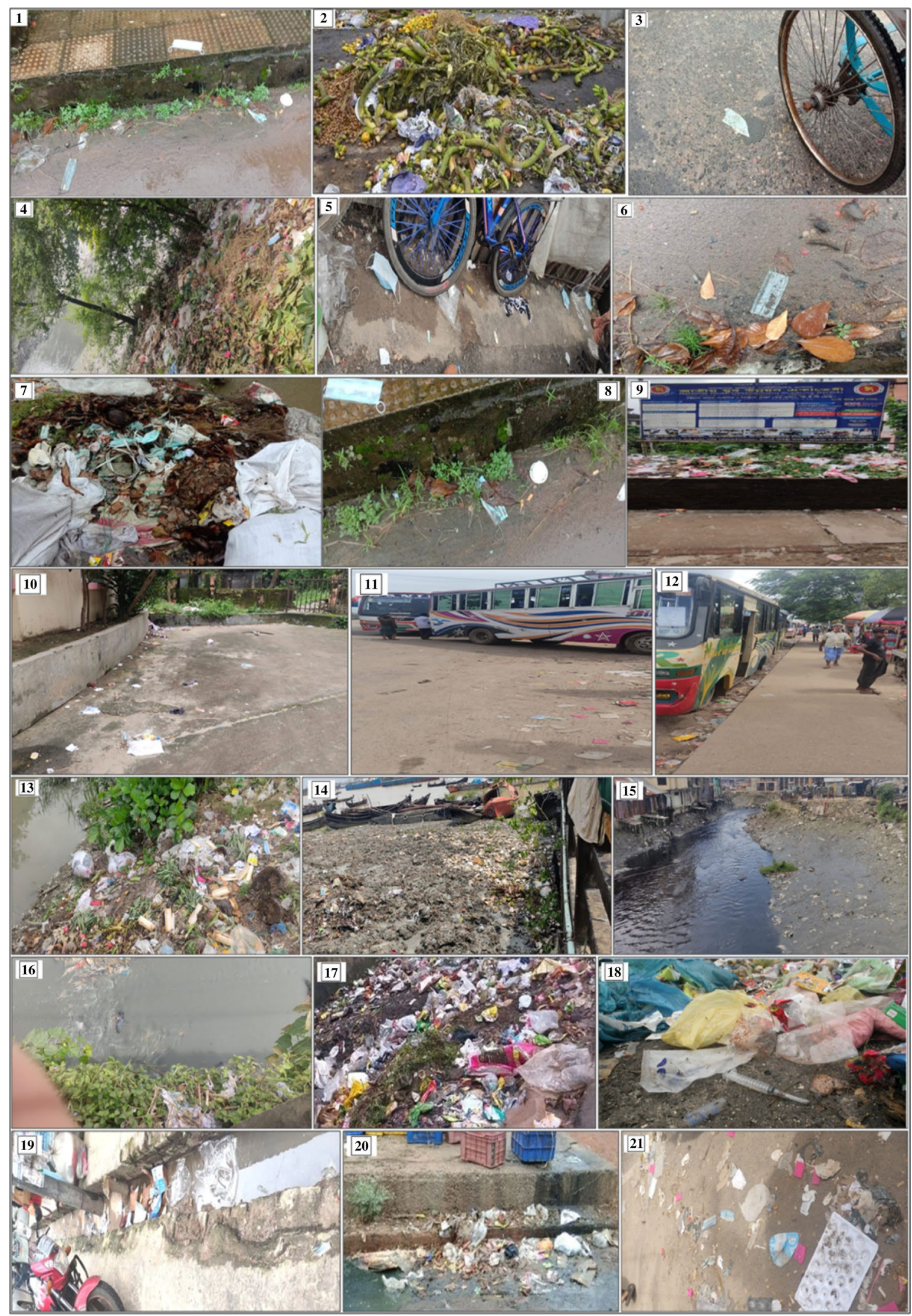

Fig. 3 PPE abundance and sampling in different surveyed locations 
Table 1 Summary of the surveyed locations and corresponding PPE abundance. Note that, during the sampling campaign period, the government of Bangladesh imposed a 2-weeks countrywide lockdown, and within that period, the prevalence of PPE wastes was observed to be low compared to the normal time

\begin{tabular}{|c|c|c|c|c|}
\hline \multirow{2}{*}{$\begin{array}{l}\text { Surveyed locations } \\
\text { and sampling code }\end{array}$} & \multirow[t]{2}{*}{ Surveyed area $\left(\mathrm{m}^{2}\right)$} & \multirow[t]{2}{*}{ PPE density (items $/ \mathrm{m}^{2}$ ) } & \multicolumn{2}{|c|}{ Geographical location } \\
\hline & & & Longitude & Latitude \\
\hline SA-1 & 710,500 & $3.6 \times 10^{-4}$ & $22^{\circ} 24^{\prime} 08.4^{\prime \prime} \mathrm{N}$ & $91^{\circ} 50^{\prime} 14.0^{\prime \prime} \mathrm{E}$ \\
\hline SA-2 & 54,054 & $4.6 \times 10^{-3}$ & $22^{\circ} 20^{\prime} 11.9^{\prime \prime} \mathrm{N}$ & $91^{\circ} 49^{\prime} 49.2^{\prime \prime} \mathrm{E}$ \\
\hline SA-3 & 58,823 & $4.8 \times 10^{-3}$ & $22^{\circ} 19^{\prime} 32.9^{\prime \prime} \mathrm{N}$ & $91^{\circ} 48^{\prime} 47.3^{\prime \prime} \mathrm{E}$ \\
\hline SA-4 & 50,000 & $3.7 \times 10^{-3}$ & $22^{\circ} 25^{\prime} 40.2^{\prime \prime} \mathrm{N}$ & $91^{\circ} 52^{\prime} 15.5^{\prime \prime} \mathrm{E}$ \\
\hline SA-5 & 66,743 & $2.2 \times 10^{-3}$ & $22^{\circ} 18^{\prime} 29.1^{\prime \prime} \mathrm{N}$ & $91^{\circ} 47^{\prime} 49.9^{\prime \prime} \mathrm{E}$ \\
\hline SA-6 & 76,923 & $2.4 \times 10^{-3}$ & $22^{\circ} 19^{\prime} 52.1^{\prime \prime} \mathrm{N}$ & $91^{\circ} 50^{\prime} 29.6^{\prime \prime} \mathrm{E}$ \\
\hline SA-7 & 62,500 & $2.6 \times 10^{-3}$ & $22^{\circ} 21^{\prime} 21.9^{\prime \prime} \mathrm{N}$ & $91^{\circ} 48^{\prime} 27.3^{\prime \prime} \mathrm{E}$ \\
\hline SA-8 & 909,091 & $2.9 \times 10^{-4}$ & $22^{\circ} 22^{\prime} 10.1^{\prime \prime} \mathrm{N}$ & $91^{\circ} 50^{\prime} 31.0^{\prime \prime} \mathrm{E}$ \\
\hline SA-9 & 81,289 & $1.9 \times 10^{-3}$ & $22^{\circ} 21^{\prime} 34.7^{\prime \prime} \mathrm{N}$ & $91^{\circ} 49^{\prime} 10.8^{\prime \prime} \mathrm{E}$ \\
\hline SA-10 & 142,856 & $1.3 \times 10^{-3}$ & $22^{\circ} 21^{\prime} 04.9^{\prime \prime} \mathrm{N}$ & $91^{\circ} 50^{\prime} 02.2^{\prime \prime} \mathrm{E}$ \\
\hline SA-11 & 250,000 & $2.6 \times 10^{-3}$ & $22^{\circ} 22^{\prime} 07.4^{\prime \prime} \mathrm{N}$ & $91^{\circ} 50^{\prime} 37.7^{\prime \prime} \mathrm{E}$ \\
\hline SA-12 & 50,000 & $6.8 \times 10^{-3}$ & $22^{\circ} 19^{\prime} 56.0^{\prime \prime} \mathrm{N}$ & $91^{\circ} 51^{\prime} 06.0^{\prime \prime} \mathrm{E}$ \\
\hline SA-13 & 125,000 & $1.5 \times 10^{-3}$ & $22^{\circ} 19^{\prime} 22.9^{\prime \prime} \mathrm{N}$ & $91^{\circ} 51^{\prime} 32.9^{\prime \prime} \mathrm{E}$ \\
\hline SA-14 & 333,333 & $7.5 \times 10^{-4}$ & $22^{\circ} 19^{\prime} 24.8^{\prime \prime} \mathrm{N}$ & $91^{\circ} 49^{\prime} 35.0^{\prime \prime} \mathrm{E}$ \\
\hline SA-15 & 270,000 & $1.6 \times 10^{-3}$ & $22^{\circ} 20^{\prime} 06.6^{\prime \prime} \mathrm{N}$ & $91^{\circ} 50^{\prime} 50.8^{\prime \prime} \mathrm{E}$ \\
\hline SA-16 & 254,000 & $1.1 \times 10^{-3}$ & $22^{\circ} 21^{\prime} 00.7^{\prime \prime} \mathrm{N}$ & $91^{\circ} 52^{\prime} 03.6^{\prime \prime} \mathrm{E}$ \\
\hline SA-17 & 54,000 & $4.3 \times 10^{-3}$ & $22^{\circ} 22^{\prime} 30.6^{\prime \prime} \mathrm{N}$ & $91^{\circ} 48^{\prime} 46.7^{\prime \prime} \mathrm{E}$ \\
\hline SA-18 & 65,000 & $4.3 \times 10^{-3}$ & $22^{\circ} 15^{\prime} 51.4^{\prime \prime} \mathrm{N}$ & $91^{\circ} 47^{\prime} 26.6^{\prime \prime} \mathrm{E}$ \\
\hline SA-19 & 51,000 & $2.4 \times 10^{-3}$ & $22^{\circ} 21^{\prime} 35.0^{\prime \prime} \mathrm{N}$ & $91^{\circ} 49^{\prime} 22.5^{\prime \prime} \mathrm{E}$ \\
\hline SA-20 & 45,000 & $2.9 \times 10^{-3}$ & $22^{\circ} 19^{\prime} 42.1^{\prime \prime} \mathrm{N}$ & $91^{\circ} 49^{\prime} 25.7^{\prime \prime} \mathrm{E}$ \\
\hline SA-21 & 85,000 & $1.1 \times 10^{-3}$ & $22^{\circ} 14^{\prime} 06.6^{\prime \prime} \mathrm{N}$ & $91^{\circ} 47^{\prime} 29.8^{\prime \prime} \mathrm{E}$ \\
\hline Total & $3,795,112$ & $5.3 \times 10^{-2}$ & $22^{\circ} 24^{\prime} 08.4^{\prime \prime} \mathrm{N}$ & $91^{\circ} 50^{\prime} 14.0^{\prime \prime} \mathrm{E}$ \\
\hline Mean \pm SD & & $2.8 \times 10^{-3} \pm 1.7 \times 10^{-3}$ & & \\
\hline
\end{tabular}

where $T W_{F}=$ total waste generated from facemask disposal (t), $F M_{D}=$ total face mask disposed of (pieces), and $W_{F}=$ average weight of a face mask.

The amount of waste generated from the daily disposal of face masks is estimated using the Eq. (3) (Gasperi et al. 2018; Nzediegwu and Chang, 2020; Sangkham, 2020):

$F M_{D}=P \times U p \times F M A R \times(F M G P / 10,000)$

where $F M_{D}$ represents the total number of disposed face masks (pieces), $P$ represents a total number of population, $U_{P}$ denotes the percentage of urban population $(100 \%)$, FMAR is the facemasks acceptance rate- $-80 \%$, and FMGP is used based on an assumption that one face mask is used by one person (per capita/day). It has been considered that 1 person per 10,000 throws a face mask into the dwelling environment after use of it. Note that the term " 10,000 " in Eq. (3) can only be used if one wants to calculate the total number of face masks thrown away in the environment by the user unconsciously.

\section{Estimation of medical wastes in CMA during COVID-19 in July 2021}

The amount of generated medical waste depends on the number of people infected and the average waste produced per bed (Sangkham 2020; Mol and Caldas 2020). Earlier studies reported the rate of generated medical waste in Bangladesh is $3.40 \mathrm{~kg} / \mathrm{bed} /$ day (Mol and Caldas 2020; Haque et al. 2020), and this data is adopted for analysis of medical waste in Eq. (4):

$M W_{T}=N C C \times M W G R \times D n$

where $M W_{T}=$ total medical waste (t), $M W G R=$ medical waste generation rate during COVID-19, $D n=$ number of days taken into account, $N C C=$ total number of active COVID-19 cases which can be estimated by:

$N C C=I c-D c-R c$

$I c=$ infected cases, $D c=$ death cases, $R c=$ recovered cases. 


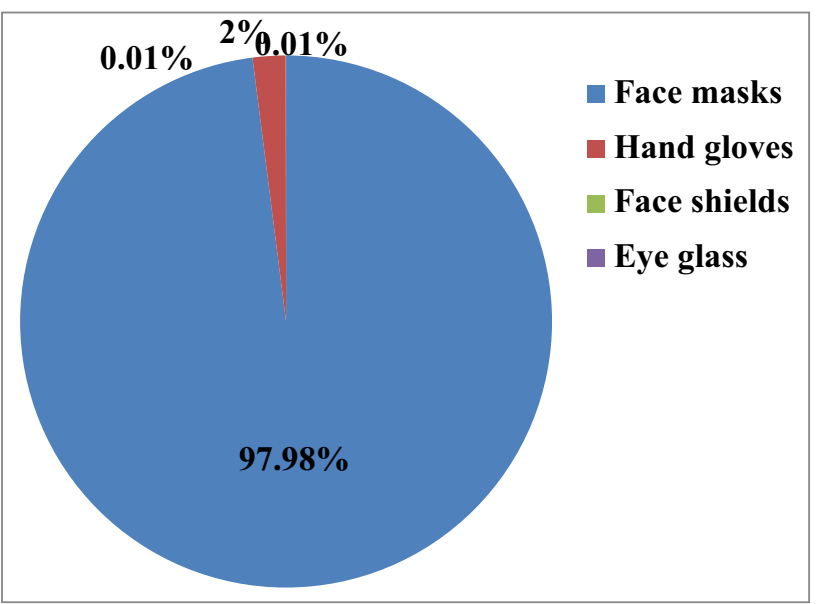

Fig. 4 Information on the PPE types in the surveyed area

\section{Estimation of medical wastes only from hospitalized COVID-19 patients in July 2021}

The total medical wastes were estimated only based on the hospitalized COVID-19 patients in CMA in July 2021. Equation (6) is used to calculate the total medical waste generated from hospitalized patients.

$M W_{(H P)}=T A H C P \times M W G R \times D n$

where $M W_{(H P)}=$ total medical waste (t) from hospitalized patients, TAHCP $=$ total active hospitalized COVID-19 patients, $M W G R=3.40 \mathrm{~kg} / \mathrm{bed} /$ day during COVID-19, and $D n=$ number of days taken into account (July $=31$ days).

\section{Results and discussion}

The present study is carried out by focusing on the total PPEs wastes generated in July 2021, and their impacts on the dwelling environment and ecosystem. Since the coronavirus
Table 4 Total medical wastes only from hospitalized COVID-19 patients during July 2021

\begin{tabular}{lllll}
\hline Sample type & TAHCP & $M W G R$ & $D n$ & $M W_{(H P)}(\mathrm{t})$ \\
\hline Medical wastes & 831 & 3.4 & 31 & 87.59 \\
\hline
\end{tabular}

is transmitted via human-to-human contact, the use of PPEs becomes mandatory to protect the general population, health staff, patients, and other service workers in this global pandemic. The rate of PPEs wastes has increased undoubtedly in the CMA during the 3rd wave of COVID-19 (see in Fig. 4). In this study, a cumulative area of $3,795,112 \mathrm{~m}^{2}$ was surveyed throughout the metropolis (Table 1 ). The face mask comprised the majority of the portion in the total PPEs, and the others were $2 \%$ hand gloves, $0.01 \%$ eyeglass, $0.01 \%$ face shields, and eye-protective glass. The highest rate of PPEs was observed during the Eid Ul Adha festival. The mean PPE density was calculated to be $2.8 \times 10^{-3} \mathrm{PPE} \mathrm{m}^{-2}$ with a standard deviation of $1.7 \times 10^{-3}$. All PPEs are non-degradable microplastic products; therefore, they may remain in the atmosphere for a long time, hence considered the biggest environmental problem at this time.

Table 2 represents the total facemask wastes from the general population in CMA. The calculated total facemask waste generated by the population of CMA in July 2021 is 3818.95 ton. Since the SARS-CoV-2 virus survives up to 3 days on plastics, therefore, this provides an alarming indication for the unaffected population as well as the environment and ecosystem. We know that most people (except health professionals) are unaware of the bad impacts of throwing face masks in the environment. It is observed that most of the low-income people move to the city for their daily livelihood, and the majority of them throw the face mask in the environment after the single use. In addition, there exists a lack of strict adherence to the proper management of daily facemask wastes in the environment of the metropolitan area. Same facemask wastes were observed in the same places during our next day of surveying. The

Table 2 Total facemask wastes generated by the general population in Chittagong metropolitan area

\begin{tabular}{llllllll}
\hline City & Population & $\begin{array}{l}\text { Urban popula- } \\
\text { tion }(\%)\end{array}$ & $\begin{array}{l}\text { Facemask } \\
\text { acceptance rate } \\
(\%)\end{array}$ & $\begin{array}{l}\text { Total facemask } \\
\text { disposal per } \\
\text { day }\end{array}$ & $\begin{array}{l}\text { Average weight } \\
\text { of a facemask } \\
(\mathrm{g})\end{array}$ & $\begin{array}{l}\text { Waste gener- } \\
\text { ated (t/day) }\end{array}$ & $\begin{array}{l}\text { Number of } \\
\text { days taken into } \\
\text { account }\end{array}$ \\
\hline Chittagong & $5,133,000$ & 100 & 80 & $4,106,400$ & 30 & 123.192 & 31 \\
\hline
\end{tabular}

Population source: https://www.macrotrends.net/cities/20115/chittagong/population

Table 3 Total medical waste in CMA during the 3rd wave of COVID-19 in July 2021

\begin{tabular}{llllllll}
\hline Sample type & $I c$ & $D c$ & $R c$ & $N C C$ & $M W G R$ & $D n$ & $M W_{T}(\mathrm{t})$ \\
\hline Medical wastes & 15,825 & 106 & 1445 & 14,274 & 3.4 & 31 & 1504.48 \\
\hline
\end{tabular}


continuous rainfall in July 2021 has carried these facemasks wastes into the city drains and finally deposited them in the Karnafully river, no doubt. Table 3 shows the estimated total medical wastes by general and active patients in CMA during July 2021.

Table 4 showed the total medical wastes of 87.59 t only from hospitalized COVID-19 patients in the CMA during July 2021. In this COVID-19 3rd wave, the amount of medical wastes has become the major problematic and sensitive issue in the CMA. Medical wastes are not separated in the source points based on their classification, and simply dumping them in the dustbin located in the hospital area. Even many clinics and laboratories keep their wastes in the nearby dustbins or temporary garbage dumping places on the road. These wastes are spread in the surrounding environment and drained by the rainfall and wind, and finally deposited in the Karnafully River and contaminating the aquatic environment. Various hazardous gases can also release from these medical wastes especially from clinical wastes such as syringes, surgical face masks, and medicine bottles. That's why general people, as well as the waste collector, may be affected by respiratory diseases. This is because of not strictly following the "medical waste management Act 2008" policy (Nielsen et al. 2020). Recent research conducted by Bracon "effective management of medical waste during COVID-19" stated that only $6.6 \%$ of medical wastes were managed properly and the rest of the $93.4 \%$ wastes were not under the control of proper management (MOEF 2008). An article "COVID-19 medical waste: Bangladesh perspective" published in the "The Lancet Global Health" reported that during the 1st stage of COVID-19 the medical wastes per bed (hospital) was in the range of $1.63-1.99 \mathrm{~kg}$ in the capital city of Bangladesh (Rahman 2013). However, in this third stage of the COVID-19 pandemic, it has increased to $3.40 \mathrm{~kg}$ in Bangladesh (Haque et al. 2020). This is because the use of one-time microplastic equipment related to COVID-19 treatments has increased tremendously.

\section{Environmental impact of PPE wastes}

The increasing production and subsequent uses of PPEs have added vast plastic and plastic wastes to the environment and aquatic ecosystem. The presence of these wastes is responsible for aquatic and environmental pollution during the COVID-19 pandemic. This is because municipal solid wastes have increased due to the COVID-19 pandemic in the CMA. Moreover, the COVID-19 pandemic has caused landfills pollution where hazardous PPE wastes are dumped without any pre-treatment or proper management. Besides this, it has been observed that, during our part of surveying in the Eid-Ul-Adha festival time, significant amounts of face masks and hand gloves were indiscriminately thrown at the animal markets in CMA. Once PPEs are released into the environment, they may react with air particles and become a source of hazardous exposure.

However, limited resources for proper PPE waste management in CMA are creating both environmental and public health problems (Lettieri 2020). The production process of disposable PPEs releases greenhouse gases into the environment. The prevalence of such gases may react with municipal wastes and generate microplastics which are then deposited in the dwelling environment (Shruti et al. 2020). Since soil is the best absorber, the longtime deposition of these microplastics can decrease soil fertility, as well as hamper plants and others species' growth properly. As a result of anaerobic environments, plastics part of PPEs degrade to form microplastics via various physical and chemical activities (Shruti et al. 2020). Moreover, various microbial activities may accelerate the rate of transformation of PPEs to MPs compared to soil in open dumps areas (Shruti et al. 2020; Silva et al. 2021). Degradation of nonwoven materials generates synthetic micro- and nano-fibers during exposure to environmental conditions (Arkatkar et al. 2009). In addition, during the use of nonwoven mask fibers may release due to sunlight exposure, and hence potentially inhaled (Muenmee et al. 2015). Weathering of plastics mainly occurs by solar UV oxidation, low rate of biodegradation, and hydrolysis delamination which accumulate in the environment (Aragaw 2020). If microplastics enter the human body, they may cause oxidative stress which can increase mortality, negatively affect the reproductive organ and growth (Li et al. 2021). Maximum slum dwellers in the CMA use water from ponds, canals, and rivers where a higher amount of PPE wastes was observed during this survey. As water becomes trapped in plastic, the microplastics cause flooding and provide a suitable habitat for breeding for mosquitoes and other water-borne diseases. As a result, people are suffering from various diseases like Dengue recently.

\section{Microplastic pollution in the aquatic ecosystem}

The extensive uses of PPE generate tones of microplastic (MP) wastes and contaminate the environment continuously. Due to the lack of proper waste management, the PPEs wastes are found in every place of the metropolitan area such as roads, parks, and drains. All MP wastes are ultimately channeled into the Karnafully River via the open drainage system in CMA. Recent continuous heavy rainfall played a vital role in this regard. As a result, aquatic pollution is increasing significantly day by day in the Karnafully River. When MPs (i.e., PPEs) are mixed with the aquatic ecosystem, they have observed different fates, and finally sink based on their density and other physical characteristics (Fig. 5). The MPs having high density (greater than $1.03 \mathrm{~g} \mathrm{~cm}^{-3}$ ) usually sink and reach the bottom sediments. On the other hand, MPs of low density 
Fig. 5 Water and sediments pollution due to the face mask in the aquatic ecosystem

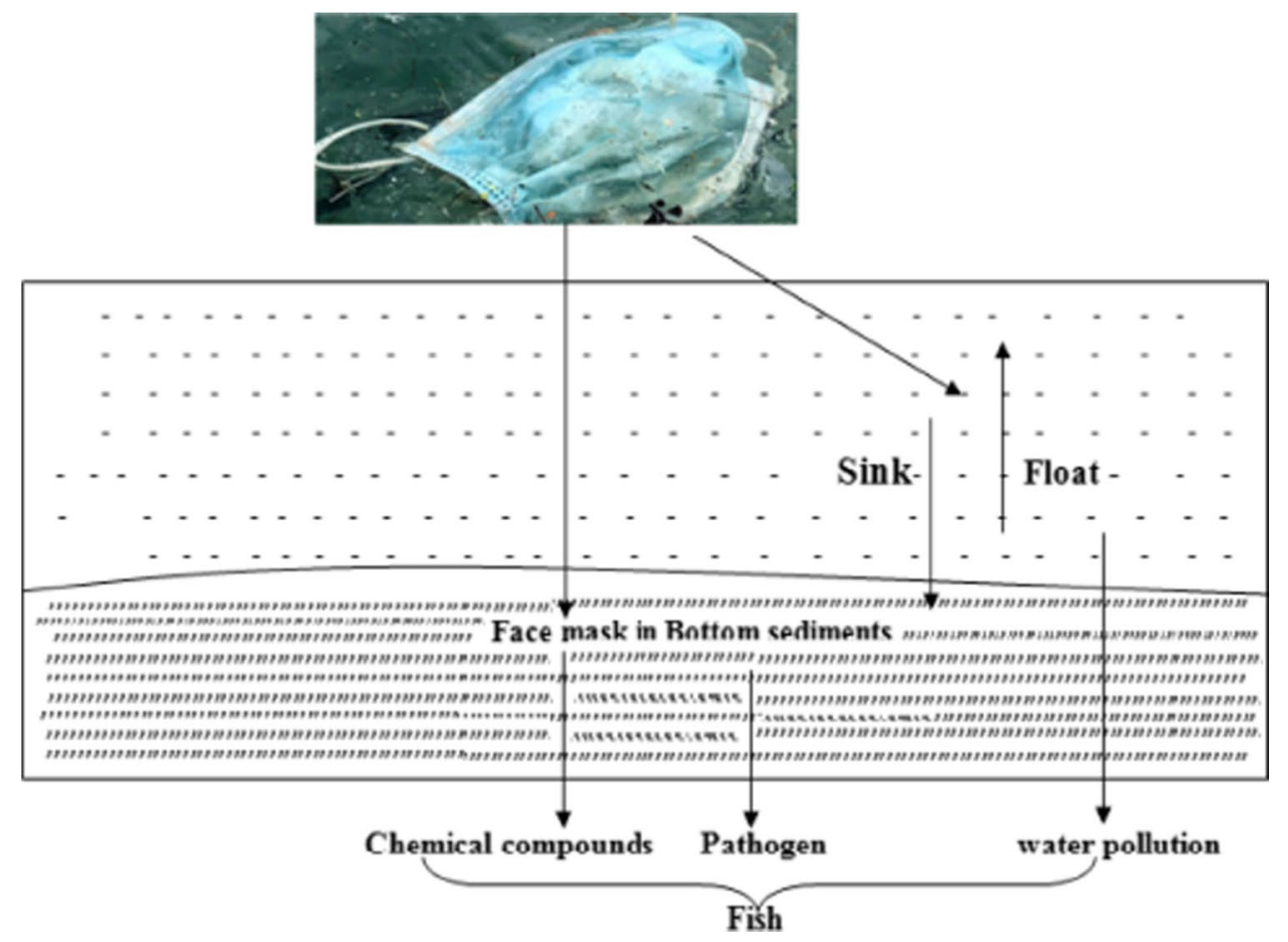

$\left(<1.03 \mathrm{~g} \mathrm{~cm}^{-3}\right)$ float in the water. The chemical compositions of PPEs react with the sediments and water, and finally produce hazardous gases and components in the aquatic ecosystem, which then pollute the waterbody and sediment, undoubtedly. Moreover, these wastes degrade over time, releasing smaller MPs, hence posing a significant risk to aquatic ecosystems. In this way, COVID-19 is responsible not only for human health risks but also for environmental and aquatic pollution. It has been estimated that, globally, more than 65 billion disposable gloves and 129 billion single-use masks are used every month, and most of them end up in the rivers and oceans. The present survey showed that the majority of the PPE wastes were face masks. Therefore, the increased use and subsequent disposal of PPEs, slow biotic decomposition followed by their accumulation in the environment leads to adverse effects in the aquatic environment. According to MP characterization, microplastics entering the aquatic environment may remain for tens of years, and then be fragmented via the various mechanical and photochemical processes resulting in the formation of smaller size microplastics or nano plastics $(<1 \mu \mathrm{m})$ (Jeong and Choi 2019). The presence of such a small size of MPs in the aquatic environment is uptake via a wide range of aquatic species, thus undergoing disturbance to their physiological functions through the food web and ultimately creating an adverse effect on human health (Espinosa et al. 2016). Moreover, floatable and sinkable MPs in the aquatic environment act as a carrier for the transfer of pollutants (Thushari and Senevirathna 2020) to the aquatic organisms (Rodrigues et al. 2019; Cozar et al. 2014), which potentially cause various detrimental and cytotoxic effects. Since the inhabitants of Chittagong city and other nearby areas are the ultimate consumers of Karnafully River fish where a high rate of MPs contamination is suspected, therefore, the probability of transfer of a significant amount of MPs to human health can't be overlooked (Yang et al. 2020; Frias and Nash 2019). In fact, the unplanned waste disposals may endanger the ecology of the riverine habitats of the Karnafully River.

\section{Public health impacts}

In Bangladesh, two types of healthcare wastes are producedhazardous and non-hazardous. Hazardous waste, including pathological, viral, sharps, and chemical wastes, are usually produced in hospital wards, operation rooms, labs, etc. Nonhazardous medical waste is typically common waste that has no specific handling protocol or environmental issues. The COVID-19 pandemic has also impacted waste treatment and disposal facilities. Before the pandemic, many industries had begun recycling activities to show their commitment in protecting the earth. Following the multifaceted economic catastrophe (Hafez et al., 2021; Sharun et al., 2021) created by the pandemic, policymakers and industry personnel have been reluctant to live up with their commitments. Most of these wastes were generated from ICU units, patients' ward areas, out-patient departments, caring homes, kitchens, etc.

Additionally, a rapid increase of toxic waste and plasticbased products disrupted the normal recycling capability as well as other waste management methods, and also, there 
was fear of coronavirus infection, which initially forced them to stop recycling activities. Furthermore, a shortage of manpower, high overhead, and the threat of COVID-19 infection has forced the industry to stop its recycling activities, which, in turn, increased the waste volume (The Daily Star 2020).

Due to the lack of proper disposal facilities, the healthcare waste could put the health of waste collectors at higher risk. Improper collection of PPE wastes would likely threaten the health of the general population. Exposure to PPE pollutants from COVID-19 can occur via both direct and indirect pathways. Potentially hazardous heavy metals $\mathrm{Cd}$ and $\mathrm{Pb}$ as well as organic chemicals and additives such as surfactants, plastic oligomers, and dye-like molecules leachates from the commercially available low-quality face masks produced by illegal/unauthorized companies in the CMA. It is totally a non-avoidable issue to investigate the long-term health risks posed by face masks. This exposure occurs through three pathways such as inhalation, dermal contact, and ingestion. The primary route of biological entry of MPs to the human body is inhalation (Barboza et al. 2018), and it has been reported that a person inhales between 26 and 130 MPs/day (Rahman et al. 2021). Such airborne MPs are sourced from synthetic fibers shed from textiles and clothing and abraded plastic materials (Rahman et al. 2021). There have been several possible health threats for healthcare staff, informal waste collectors, and the citizens that live close to the temporary waste disposal areas due to the lack of proper disposal systems in the hospital. Sanitation workers face a greater risk of infection, injury, and death than average workers, and they rarely have access to health services.

Infectious MP wastes contain pathogens such as viruses, bacteria, fungi, or parasites that can cause disease in liable hosts. The ubiquitous of smaller size $(<5 \mathrm{~mm})$ of PPE debris is reported in air, soil, water, living organisms, processed food, and even in drinking water (Cowger et al. 2020; Prata 2018; Mohammad et al. 2019; Amato-Lourenço et al. 2020). The ingestion of MPs has impacts on blood, bodily fluids, organs, tissues, and so on (Rahman et al. 2020; Thompson 2015). Prata et al. (2019) reported that the MPs in the lungs can cause lung inflammation leading to cytotoxic effects in the respiratory system (Dris et al. 2016). In addition, COVID-19-generated infectious wastes or PPEs have posed a worldwide concern to human and environmental health (WHO 2017). That's why the mismanaged PPE wastes may increase the spread of coronavirus (Saadat et al. 2020). Another concerning issue is that some unauthorized companies produce low-quality PPEs which create various respiratory diseases due to the use of potentially hazardous materials and chemicals in the production of PPEs.

\section{Summary and recommendations to minimize the PPE's pollution}

Globally, the production and use of PPEs see a rapid increase following the COVID-19 pandemic; therefore, the management of PPE wastes should be done properly. As microplastics are derived from PPEs, there is a high possibility of human exposure to PPE-derived pollutants via various pathways. The following steps may be applied to minimize the PPE's pollution in this COVID-19 pandemic.

- Reusable PPEs can be used as a safe and eco-friendly alternative to protect from SARS-CoV-2 transmission. Reusable PPEs can be made using synthetic materials, which can reduce MP contamination to the dwelling environment. The greater use of reusable face masks is reported to reduce the PPEs waste by $85 \%$, makes 3.5 times lower impact on climate change, also offers 3.7 times cheaper than the single-use PPE. Therefore, reusable PPEs are not only helpful for a greener environment but also a public health issue. To facilitate proper disposal of PPE's by the public, the municipality authority should deploy enough waste bins in various public places, also ensure the collection of PPE wastes frequently.

- The general public should be inspired/educated via press and electronic media to reduce the use of one-time PPEs (i.e., gloves) and wash hands frequently instead.

- Ensuring enough supply of high-quality reusable face masks that can be frequently disinfected.

- Ensuring greater media coverage on the negative impact of indiscriminate disposal of PPEs and educating better practices through promotional videos and educational campaigns.

- The recycling of PPE wastes offers a greater benefit to society; therefore, such an initiative should be taken to reduce the pollution of dwelling and aquatic environment.

\section{Limitation of the study}

This study provides a rapid estimation of the PPE wastes associated with the 3 rd wave of COVID-19 pandemic in Chittagong city, Bangladesh. The accuracy of the estimated data largely depends on various factors including the survey parameters, PPE abundance, and waste generation rates $(\mathrm{kg} /$ bed/day). It should be mentioned that there was a 2 -week lockdown during the sampling campaign month; consequently, the observed PPE wastes must be lower than the normal time. 


\section{Conclusion and future outlook}

This study analyzed the PPE wastes generated during the 3rd wave of COVID-19 in the Chittagong metropolitan area, Bangladesh. It has also addressed the impact of PPE wastes contamination on the terrestrial and aquatic ecosystem. The widespread use of PPE is the major source of microplastics in our environment. Organic pollutants and other micropollutants from PPE wastes may pose a potential risk to the environment and public health. Based on the evaluated data, the COVID-19 pandemic is responsible for contaminating the environment through the disposal of PPE wastes. This study revealed that PPE wastes increased with the increase of infected patients.

However, little information is available on the phase partitioning of PPE wastes derived from microplastics and associated contaminants among aquatic components such as various sizes, fractions of sediments, plants, and other organisms such as fish. The degradation and fate of MPs along the transfer pathway from the source into the human food chain are yet to be investigated, and finally, the sinking of microplastics in sediments due to physical or biological phenomena requires detailed future study. A detailed study should be conducted by addressing the ecotoxicology of microplastics and how they interact with other pollutants in aquatic environments.

\begin{abstract}
Author contribution Md. Jainal Abedin, Mayeen Uddin Khandakerconceptualization, methodology, writing the draft, software. Md. Jainal Abedin, Md. Ripaj Uddin, Md. Rezaul Karim-data curation, writing (original draft preparation). Shahab Uddin Ahamad, Md. Ariful Islam, Abu Mohammad Arif-visualization, investigation. Mayeen Uddin Khandaker-supervision, reviewing the original draft. Abubakr M. Idris-software, validation. Md. Jainal Abedin, Mayeen Uddin Khandaker-writing (reviewing, editing, and funding).
\end{abstract}

Funding The authors extend their appreciation to the Deanship of Scientific Research at King Khalid University for funding this work through Group Research Project under grant number (R.G.P.2/33/42). King Khalid University,R.G.P.2/33/42,Abubakr M. Idris

Data Availability All data are available in the manuscript.

\section{Declarations}

Ethical approval Not applicable.

Consent to participate Not applicable.

Consent for publication All authors are agreed to this submission and publish in ESPR if accepted.

Competing interests The authors declare no competing interests.

\section{References}

Amato-Lourenço LF, Santos GL, Weger LA, Hiemstra PS, Vijver MG, Mauad T (2020) An emerging class of air pollutants: potential effects of microplastics to respiratory human health. Sci Total Environ 749:1-7

Andrady AL (2017) The plastic in microplastics: a review. Mar Pollut Bull 119:12-22. https://doi.org/10.1016/j.marpolbul.2017.01.082

Aragaw TA (2020) Surgical face masks as a potential source for microplastic pollution in the COVID-19scenario. Mar Pollut Bull 159:111517

Arkatkar A, Arutchelvi J, Bhaduri S, Uppara PV, Doble M (2009) Degradation of unpretreated and thermally pretreated polypropylene by soil consortia. Int Biodeterior Biodegrad 63:106-111

Arwady MA, Alraddadi B, Basler C, Azhar EI, Abuelzein E, Sindy AI, Sadiq BMB, Althaqafi AO, Shabouni O, Banjar A, Haynes LM, Gerber SI, Feikin DR, Madani TA (2016) Middle East respiratory syndrome coronavirus transmission in extended family, Saudi Arabia. Emerg Infect Dis 22:1395-1402. https://doi.org/10. 3201/eid2208.152015

Barboza LGA, Dick VA, Lavorante BRBO, Lundebye AK, Guilhermino L (2018) Marine microplastic debris: an emerging issue for food security, food safety and human health. Mar Pollut Bull 133:336-348

Boroujeni M, Saberian M, Li J (2021) Environmental impacts of COVID-19 on Victoria, Australia, witnessed two waves of coronavirus. Environ Sci Pollut Res 1-10https://doi.org/10.1007/ s11356-021-12556-y

CMA population (2021) Available at https://www.macrotrends.net/cities/20115/chittagong/population. Accessed 3 Dec 2021

Chua MH, Cheng W, Goh SS, Kong J, Li B, Lim JYC, Mao L, Wang S, Xue KY (2020) Face masks in the new COVID-19 normal: materials, testing, and perspectives. Research 1-40.

Cowger W, Gray A, Christiansen SH (2020) Critical review of processing and classification techniques for images and spectra in microplastic research. Appl Spectrosc 74:989-1010. https://doi. org/10.1177/0003702820929064

Cozar A, Echevarria F, Gonzalez-Gordillo JI (2014) Plastic debris in the open ocean. PNAS 1-6https://doi.org/10.1073/pnas.13147 05111

Dietz L, Horve PF, Coil DA, Fretz M, Eisen JA, Van-Den WK (2020) Novel coronavirus (COVID-19) pandemic: built environment considerations to reduce transmission. mSystems 5:1-14. https://doi. org/10.1128/mSystems.00245-20

Doremalen NV, Bushmaker T, Morris DH, Holbrook MG, Gamble A, Williamson BN, Tamin A, Harcourt JL, Thornburg NJ, Gerber SI, Lloyd-Smith JO, Wit E, Munster VJ (2020) Aerosol and surface stability of SARS-CoV-2 as compared with SARS-CoV-1. N Engl J Med 382:1564-1567. https://doi.org/10.1056/NEJMc2004973

Dris R, Gasperi J, Saad M, Mirande C, Tassin B (2016) Synthetic fibers in atmospheric fallout: a source of microplastics in the environment? Mar Pollut Bull 104(290-278):293

Espinosa C, Esteban MÁ, Cuesta A (2016) Microplastics in aquatic environments and their toxicological implications for fish. Toxicology New Aspects to This Scientific Conundrum. InTech. 1-36. https://doi.org/10.5772/64815

Fadare OO, Okoffo ED (2020) COVID-19 face masks: a potential source of microplastic fibers in the environment. Sci Total Environ $737: 1-4$

Fadare OO, Wan B, Guo L, Zhao L (2020) Microplastics from consumer plastic food containers: are we consuming it? Chemosphere 253:126787

Fahmida P, Shumya J, Sharif MT (2021) Abundance, characteristics and variation of microplastics in different freshwater fish species from Bangladesh. Sci Total Environ 784:147137 
Ferronato N, Torretta V (2019) Waste mismanagement in developing countries: a review of global issues. Int J Environ Res Publ Health 16:1060

Frère L, Maignien L, Chalopin M, Huvet A, Rinnert E, Morrison H, Kerninon S, Cassone AL, Lambert C, Reveillaud J, Paul-Pont I (2018) Microplastic bacterial communities in the Bay of Brest: influence of polymer type and size. Environ Pollut 242:614-625. https://doi.org/10.1016/j.envpol.2018.07.023

Frias JPGL, Nash R (2019) Microplastics: finding a consensus on the definition. Mar Pollut Bull 138:145-147. https://doi.org/10. 1016/j.marpolbul.2018.11.022

Gasperi J, Wright SL, Dris R, Collard F, Mandin C, Guerrouache M, Langlois V, Kelly FJ, Tassin B (2018) Microplastics in air: are we breathing it in? Curr Opin Environ SciHeal 1:1-5

Hafez, M. H., Y.A. Attia, Fulvia Bovera, Asmaa F. Khafaga, Mohamed E. Abd El-Hack and M. Cristina de olviera (2021). SARS-CoV-2 impact on the poultry industry and environment. Environmental Science and Pollution Research . 202110.1007/ s11356-021-15052

Haque MS, Uddin S, Sayem SM, Mohib KM (2020) Coronavirus disease 2019 (COVID-19) induced waste scenario: a short overview. J Env Chem Eng 9:104660. https://doi.org/10.1016/j.jece. 2020.104660

Hossain MS, Sobhan F, Uddin MN, Sharifuzzaman SM, Chowdhury SR, Sarker S, Chowdhury MSN (2019) Microplastics in fishes from the Northern Bay of Bengal. Sci Total Environ 690:821-830. https://doi.org/10.1016/j.scitotenv.2019.07.065

Jagrata Juba Shangha (2021) COVID-19 impacts on waste in Bangladesh. Available at (http://www.jjsbangladesh.org) 1-38

Jeong J, Choi J (2019) Adverse outcome pathways potentially related to hazard identification of microplastics based on toxicity mechanisms. Chemosphere 231:249-255

Kampf G, Todt D, Pfaender S, Steinmann E (2020) Persistence of coronaviruses on inanimate surfaces and their inactivation with biocidal agents. J Hosp Infect 104:246-251

Lettieri P (2020) The environmental dangers of employing single-use face masks as part of a COVID-19strategy. UCL Open Environ $1-40$

Li L, Zhao X, Li Z, Song K (2021) COVID-19: performance study of microplastic inhalation risk posed by wearing masks. J Hazard Mater 411:124955

Liubartseva S, Coppini G, Lecci R, Creti S (2016) Regional approach to modeling the transport of floating plastic debris in the Adriatic Sea. Mar Pollut Bull 103:115-127. https://doi.org/10.1016/j. marpolbul.2015.12.031

MOEF (2008) The medical waste management rules, 2008 - Chancery Law Chronicles. http://www.clcbd.org/document/133.html

Mohammad SH, Faisal S, Mohammad NU, Sharifuzzaman SM, Sayedur RC, Subrata S, Mohammad SNC (2019) Microplastics in fishes from the Northern Bay of Bengal. Sci Total Environ 690:821-830

Mol MPG, Caldas S (2020) Can the human coronavirus epidemic also spread through solid waste? Waste Manag Res 38:485-486

Muenmee S, Chiemchaisri W, Chiemchaisri C (2015) Microbial consortium involving biological methane oxidation in relation to the biodegradation of waste plastics in a solid waste disposal open dump site. Int Biodeterior Biodegrad 102:172-181

Nghiem LD, Morgan B, Donner E, Short MD (2020) The COVID-19 pandemic: considerations for the waste and wastewater services sector. Case Stud Chem Environ Eng 1:1-5. https://doi.org/10. 1016/j.cscee.2020.100006

Nielsen TD, Hasselbalch J, Holmberg K, Stripple J (2020) Politics and the plastic crisis: a review throughout the plastic life cycle. In Wiley Interdisciplinary Reviews: Energy Environ 1-18https:// doi.org/10.1002/wene.360
Nzediegwu C, Chang SX (2020) Improper solid waste management increases the potential for COVID-19 spread in developing countries. Resour Conserv Recycl 161:104947

Okuku E, Kiteresi L, Owato G, Otieno K, Mwalugha C, Mbuche M, Gwada B, Nelson A, Chepkemboi P, Achieng Q, Wanjeri V, Ndwiga J, Mulupi L, Omire J (2020) The impacts of COVID-19 pandemic on marine litter pollution along the Kenyan coast: a synthesis after 100 days following the first reported case in Kenya. Mar Pollut Bull 162:111840. https://doi.org/10.1016/j.marpolbul. 2020.111840

Patel A, D'Alessandro MM, Ireland KJ, Burel WG, Wencil EB, Rasmussen SA (2017) Personal protective equipment supply chain: lessons learned from recent public health emergency responses. Health Secur 15:244-252. https://doi.org/10.1089/hs.2016.0129

Perlman S (2020) Another decade, another coronavirus. N Engl J Med 382:760-762. https://doi.org/10.1056/NEJMe2001126

Portuguese Environment Agency (2020) Gestao de resíduosemsituação de pandemiapor SARS-CoV-2 (COVID-19) [waste management in a pandemic by SARS-CoV-2 (COVID-19)] https://apambiente. pt/_zdata/Instituicao/Imprensa/2020/Nota_OCS_2020-19_Gesta oResiduos_SituacaoPandemia.pdf

Prata JC (2018) Airborne microplastics: consequences to human health? Environ Pollut 234:115-126

Prata JC, Silva ALP, Da Costa JP, Mouneyrac C, Walker TR, Duarte AC, Rocha-Santos T (2019) Solutions and integrated strategies for the control and mitigation of plastic and microplastic pollution. Int J Environ Res Public Health 16:2411. https://doi.org/10.3390/ ijerph16132411

Prather KA, Wang CC, Schooley RT (2020) Reducing the transmission of SARS-CoV-2. Science 368:1422-1424

Rahman KA (2013) Survey on quantitative and qualitative assessment of medical waste generation and management in Dhaka North City Corporation and Dhaka South City Corporation. PRISM Bangladesh. http://pbf.org.bd/wp-content/uploads/2014/01/Survey-onQuantitative-qualitativeassessment-ofmedical-waste-generationandmanagemant-in-DNCC-DSCC.pdf (accessedJuly 22, 2020)

Rahman A, Sarkar A, Yadav OP, Achari G, Slobodnik J (2021) Potential human health risks due to environmental exposure to nano- and microplastics and knowledge gaps: a scoping review. Sci Total Environ 757:143872. https://doi.org/10.1016/j.scitotenv.2020.1438

Rahman SMA, Robin GS, Momotaj M, Uddin J, Siddique MAM (2020) Occurrence and spatial distribution of microplastics in beach sediments of Cox's Bazar, Bangladesh. Mar Pollut Bull 160:1-10

Reid AJ, Carlson AK, Creed IF, Eliason EJ, Gell PA, Johnson PTJ, Kidd KA, MacCormack TJ, Olden JD, Ormerod SJ, Smol JP, Taylor W, Tockner K, Vermaire JC, Dudgeon D, Cooke SJ (2019) Emerging threats and persistent conservation challenges for freshwater biodiversity. Biol Rev 94:849-873

Rodrigues JP, Duarte AC, Santos-Echeandia J, Rocha-Santos T (2019) Significance of interactions between microplastics and POPs in the marine environment: a critical overview. TrAC Trends Anal Chem 111:252-260. https://doi.org/10.1016/j.trac.2018.11.038

Saadat S, Rawtani D, Hussain CM (2020) Environmental perspective of COVID-19. Sci Total Environ 728:138870. https://doi.org/10. 1016/j.scitotenv.2020.138870

Sangkham S (2020) Face mask and medical waste disposal during the novel COVID-19 pandemic in Asia. Case Studies in Chem Environ Eng 2:100052. https://doi.org/10.1016/j.cscee.2020.100052

Sharun K., Dhama K., Pawde A.M., Gortázarc C., Tiwari Ruchi, Bonilla-Aldana D. Katterine, Rodriguez-Morales Alfonso J., de la Fuente José, Michalak Izabela and Attia Y. A., (2021). SARSCoV-2 in animals: potential for unknown reservoir hosts and public health implications veterinary quarterly (TVEQ). https://doi. org/10.1080/01652176.2021.1921311 
Shen M, Ye S, Zeng G, Zhang Y, Xing L, Tang W, Wen X, Liu S (2019) Can microplastics pose a threat to ocean carbon sequestration? Mar Pollut Bull 137:157-171

Shruti VC, Pérez-Guevara F, Elizalde-Martínez I, Kutralam-Muniasamy G (2020) Reusable masks for COVID-19: a missing piece of the microplastic problem during the global health crisis. Mar Pollut Bull 161:111777

Silva ALP, Prata JC, Duarte AC, Soares AMVM, Barcelo D, RochaSantos T (2021) Microplastics in landfill leachates: the need for reconnaissance studies and remediation technologies. Case Stud Chem Environ Eng 3:100072

Singh N, Tang Y, Zhang Z, Zheng C (2020) COVID-19 waste management: effective and successful measures in Wuhan, China. Resour Conserv Recycl 163:105071

The Daily Star (2020) The rise in plastic pollution during Covid-19 crisis I The Daily Star. https://www.thedailystar.net/opinion/news/ the-rise-plastic-pollution-during-covid-19-crisis1931925

Thompson RC (2015) Microplastics in the marine environment: sources, consequences and solutions. In Marine Anthropogenic Litter 185-200

Thushari GGN, Senevirathna JDM (2020) Plastic pollution in the marine environment. Heliyon 6:1-16. https://doi.org/10.1016/j. heliyon.2020.e04709

WHO (2017) Safe management of wastes from health-care activities: a summary. https://apps.who.int/iris/bitstream/handle/10665/ 259491/WHO-FWC-WSH-17.05-eng.pdf?sequence=1. (Accessed 1 September 2020).
WHO (2020) Water, sanitation, hygiene, and waste management for the COVID-19 virus https://www.who.int/publications-detail/watersanitation-hygiene-and-waste-management-for-the-COVID-19virus-interim-guidance.

Windfeld ES, Brooks MSL (2015) Medical waste management -a review. J Environ Manage 163:98-108. https://doi.org/10.1016/j. jenvman.2015.08.013

World Bank (2019) Solid waste management. https://www.worldbank. org/en/to pic/urban development/brief/solid-waste-management. (Accessed 14 July 2020).

Yang Y, Liu W, Zhang Z (2020) Microplastics provide new microbial niches in aquatic environments. App Biotech 104:6501-6511. https://doi.org/10.1007/s00253-020-10704-x

Young K (2020) What do we know about COVID-19 transmission? Emerg Med News 42:1-14. https://doi.org/10.1097/01.EEM. 0000668064.35396.f0

Zeri F, Naroo SA (2020) Contact lens practice in the time of COVID-19. Contact Lens Anterior Eye 43:193-195. https://doi.org/10.1016/j.clae. 2020.03.007

Publisher's note Springer Nature remains neutral with regard to jurisdictional claims in published maps and institutional affiliations. 